University of Texas Rio Grande Valley

ScholarWorks @ UTRGV

\title{
Nighttime Blood Pressure Interacts with APOE Genotype to Increase the Risk of Incident Dementia of the Alzheimer's Type in Hispanics
}

\author{
Jesus D. Melgarejo \\ Daniel C. Aguirre-Acevedo \\ Ciro Gaona \\ Carlos A. Chavez \\ Gustavo E. Calmon
}

See next page for additional authors

Follow this and additional works at: https://scholarworks.utrgv.edu/som_pub

Part of the Diseases Commons

\footnotetext{
Recommended Citation

Melgarejo, J. D., Aguirre-Acevedo, D. C., Gaona, C., Chavez, C. A., Calmón, G. E., Silva, E. R., de Erausquin, G. A., Gil, M., Mena, L. J., Terwilliger, J. D., Arboleda, H., Scarmeas, N., Lee, J. H., \& Maestre, G. E. (2020). Nighttime Blood Pressure Interacts with APOE Genotype to Increase the Risk of Incident Dementia of the Alzheimer's Type in Hispanics. Journal of Alzheimer's Disease, 77(2), 569-579. https://doi.org/10.3233/ JAD-200430

This Article is brought to you for free and open access by the School of Medicine at ScholarWorks @ UTRGV. It has been accepted for inclusion in School of Medicine Publications and Presentations by an authorized administrator of ScholarWorks @ UTRGV. For more information, please contact justin.white@utrgv.edu, william.flores01@utrgv.edu.
} 


\section{Authors}

Jesus D. Melgarejo, Daniel C. Aguirre-Acevedo, Ciro Gaona, Carlos A. Chavez, Gustavo E. Calmon, Egle R. Silva, Gabriel A. de Erausquin, Mario Gil, Luis J. Mena, Joseph D. Terwilliger, Humberto Arboleda, Nikolaos Scarmeas, Joseph H. Lee, and Gladys E. Maestre 


\section{Nighttime Blood Pressure Interacts with $A P O E$ Genotype to Increase the Risk of Incident Dementia of the Alzheimer's Type in Hispanics}

Jesus D. Melgarejo a,b, Daniel C. Aguirre-Acevedo ${ }^{\mathrm{c}}$, Ciro Gaona $^{\mathrm{a}}$, Carlos A. Chavez ${ }^{\mathrm{a}}$, Gustavo E. Calmón ${ }^{\mathrm{d}}$, Eglé R. Silva ${ }^{\mathrm{d}}$, Gabriel A. de Erausquin ${ }^{\mathrm{e}, \mathrm{f}}$, Mario Gil ${ }^{\mathrm{f}, \mathrm{g}}$, Luis J. Mena $^{\mathrm{h}}$, Joseph D. Terwilliger ${ }^{\mathrm{i}, \mathrm{j}, \mathrm{k}, 1}$, Humberto Arboleda ${ }^{\mathrm{m}, \mathrm{n}}$, Nikolaos Scarmeas ${ }^{\mathrm{o}, \mathrm{p}}$, Joseph H. Lee ${ }^{\mathrm{j}, \mathrm{o}, \mathrm{q}}$ and Gladys E. Maestre ${ }^{\mathrm{a}, \mathrm{f}, \mathrm{r}, \mathrm{s}, *}$

${ }^{a}$ Laboratory of Neuroscience, University of Zulia, Maracaibo, Venezuela

${ }^{\mathrm{b}}$ Research Unit Hypertension and Cardiovascular Epidemiology, Department of Cardiovascular Sciences, KU University of Leuven, Leuven, Belgium

${ }^{\mathrm{c}}$ Medical Research Institute, School of Medicine, University of Antioquia, Medellin, Colombia

${ }^{\mathrm{d}}$ Instituto de Investigación de Enfermedades Cardiovasculares de la Universidad del Zulia, Facultad de Medicina, Universidad del Zulia, Maracaibo, Venezuela

${ }^{\mathrm{e}}$ Department of Neurology, and Glenn Biggs Institute for Alzheimer's and Neurodegenerative Diseases, University of Texas Health Sciences Center at San Antonio, San Antonio, TX, USA

f Alzheimer's Disease Resource Center for Minority Aging Research, University of Texas Rio Grande Valley, Brownsville, TX, USA

${ }^{\mathrm{g}}$ Department of Psychological Science and Department of Neurosciences, University of Texas Rio Grande Valley, School of Medicine, Edinburg, TX, USA

${ }^{\mathrm{h}}$ Department of Informatics, Universidad Politécnica de Sinaloa, Mazatlán, México

${ }^{\mathrm{i}}$ Departments of Psychiatry and Genetics \& Development, Columbia University Medical Center, New York, NY, USA

${ }^{\mathrm{j} S e r g i e v s k y ~ C e n t e r ~ \& ~ D e p a r t m e n t ~ o f ~ E p i d e m i o l o g y, ~ C o l u m b i a ~ U n i v e r s i t y ~ M e d i c a l ~ C e n t e r, ~ N e w ~ Y o r k, ~ N Y, ~ U S A ~}$

${ }^{\mathrm{k}}$ Division of Medical Genetics, New York State Psychiatric Institute, New York, NY, USA

${ }^{1}$ Division of Public Health Genomics, National Institute for Health and Welfare, Helsinki, Finland

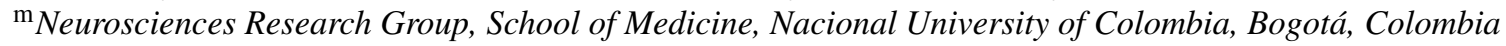

${ }^{\mathrm{n}}$ Genetic Institute, National University of Colombia, Bogotá, Colombia

${ }^{\circ}$ Taub Institute for Research on Alzheimer's Disease and the Aging Brain and Department of Neurology, College of Physicians and Surgeons, Columbia University, New York, NY, USA

$\mathrm{p}$ 1st Department of Neurology, Medical School, National and Kapodistrian University of Athens, Athens, Greece ${ }^{\mathrm{q}}$ Department of Epidemiology, School of Public Health, Columbia University, New York, NY, USA

${ }^{\mathrm{r}}$ Department of Neurosciences, University of Texas Rio Grande Valley School of Medicine, Brownsville, TX, USA

${ }^{\mathrm{s}}$ Department of Human Genetics University of Texas Rio Grande Valley School of Medicine, Brownsville,

$T X, U S A$

${ }^{*}$ Correspondence to: Gladys E. Maestre, MD, $\mathrm{PhD}$, One West University Blvd, BROBL Rm. 106, University of Texas Rio Grande Valley, Brownsville, TX 78520, USA.
Tel.: +1 956882 7495; E-mail: gladys.maestre@utrgv.edu., E-mail: gladysmaestre@gmail.com. 


\begin{abstract}
.
Background: Dementia of the Alzheimer's type (DAT) impacts Hispanics disproportionately, with almost a twofold elevated risk of developing DAT, as well as earlier onset of the disease, than in non-Hispanic Whites. However, the role of main risk factors for DAT, such as $A P O E-\varepsilon 4$ and blood pressure (BP) levels, remains uncertain among Hispanics.

Objective: To investigate the association of $A P O E-\varepsilon 4$ and BP levels, measures with 24-h ambulatory BP monitoring, with incidence of DAT in an elderly cohort of Hispanics.

Methods: 1,320 participants from the Maracaibo Aging Study, free of dementia at the baseline, and with ambulatory BP measurements and $A P O E$ genotype available were included. Adjusted Cox proportional models were performed to examine 1) the incidence of DAT and 2) the relationship between BP levels and DAT according to APOE genotypes. Models were adjusted by competing risk of death before the onset of DAT. Model performance was assessed by likelihood test.

Results: The average follow-up time was 5.3 years. DAT incidence was 5.8 per 1000 person-year. APOE- $\varepsilon 4$ carriers had a higher risk of DAT. In unadjusted analyses, conventional, 24-h, and nighttime systolic BP levels were significantly higher in participants who developed DAT and of $A P O E-\varepsilon 4$ carriers $(p<0.05)$. After adjustment for competing risks, only higher nighttime systolic BP was associated with DAT incidence, but only among subjects carrying APOE- $\varepsilon 4$.

Conclusion: In this Hispanic population, both $A P O E-\varepsilon 4$ genotype and assessment of nocturnal systolic BP (rather than diurnal or office $\mathrm{BP}$ ) were necessary to estimate DAT risk.
\end{abstract}

Keywords: Alzheimer's disease, ambulatory blood pressure monitoring, Apolipoprotein E, dementia of Alzheimer's type, Hispanics, night-time blood pressure

\section{INTRODUCTION}

Dementia of the Alzheimer's type (DAT) affects Hispanics disproportionately, with almost a twofold elevated risk of developing DAT, as well as earlier onset of the disease, than in non-Hispanic Whites $[1,2]$. Despite evidence that intensive BP control helps prevent cognitive decline and dementia [3], and that hypertension is by far the dominant reversible risk factor for $\mathrm{AD}$, risk stratification for $\mathrm{AD}$ among hypertensives is still controversial [4], especially among minority populations. Hispanics are less likely to have their blood pressure (BP) controlled than their White counterparts, even if treated with antihypertensive medications [5], and it has been suggested that the higher cardiovascular burden attributed to hypertension is partially responsible for the higher risk of DAT. Although Hispanics constitute a diverse group, the trends in BP control and the magnitude of incident DAT seem to be consistent across the United States and in Latin America and the Caribbean [6-8]. However, no previous epidemiological studies assessed the role of high BP or other known risk factors in Alzheimer's disease (AD) incidence in Hispanics.

The reason for the elevated risk of AD among Hispanics is uncertain, but is suspected to involve complex inherited and environmental factors, as well as gene-environment interactions. The apolipoprotein $\mathrm{E}(A P O E)$ gene is one of the most robust factors in the predisposition to $\mathrm{AD}$, and the role of the $\varepsilon 4$ variant is still being studied, particularly in Hispanics $[9,10]$. Since both high BP and APOE genotypes influence the odds of cardiovascular death and AD, the individual and synergistic roles of hypertension and $A P O E-\varepsilon 4$ need to be clarified. This requires long-term studies of populations that are relatively homogeneous in genetics and lifestyle. The present study used a longitudinal cohort of Venezuelans, followed for more than a decade, to test two hypotheses: 1) $A P O E$ genotype is associated with incidence of DAT, and 2) the relationship between BP and DAT risk is influenced by $A P O E$ genotype. To improve the accuracy of the results, BP was assessed using both conventional BP measurements and ambulatory BP monitoring, which provides a more reliable assessment of cardiovascular risk and a better prognostic for $\mathrm{AD}$ than conventional BP measurements [11].

\section{METHODS}

\section{Study population}

The Maracaibo Aging Study (MAS) is a longitudinal, population-based study of individuals $\geq 55$ years of age, residing in Maracaibo, Santa Lucia County, Venezuela [12]. Detailed methodology of the MAS is described elsewhere [12]. For the present study, we excluded subjects without $A P O E$ genotyping $(n=307)$ or follow-up data $(n=826)$, out of the 2,453 individuals evaluated at baseline (Fig. 1). Since the $A P O E-\varepsilon 4$ risk for DAT has been reported to be attenuated for Hispanics [10], we first tested the strength of this association with a total of 1,320 subjects that were dementia-free at baseline and who had 


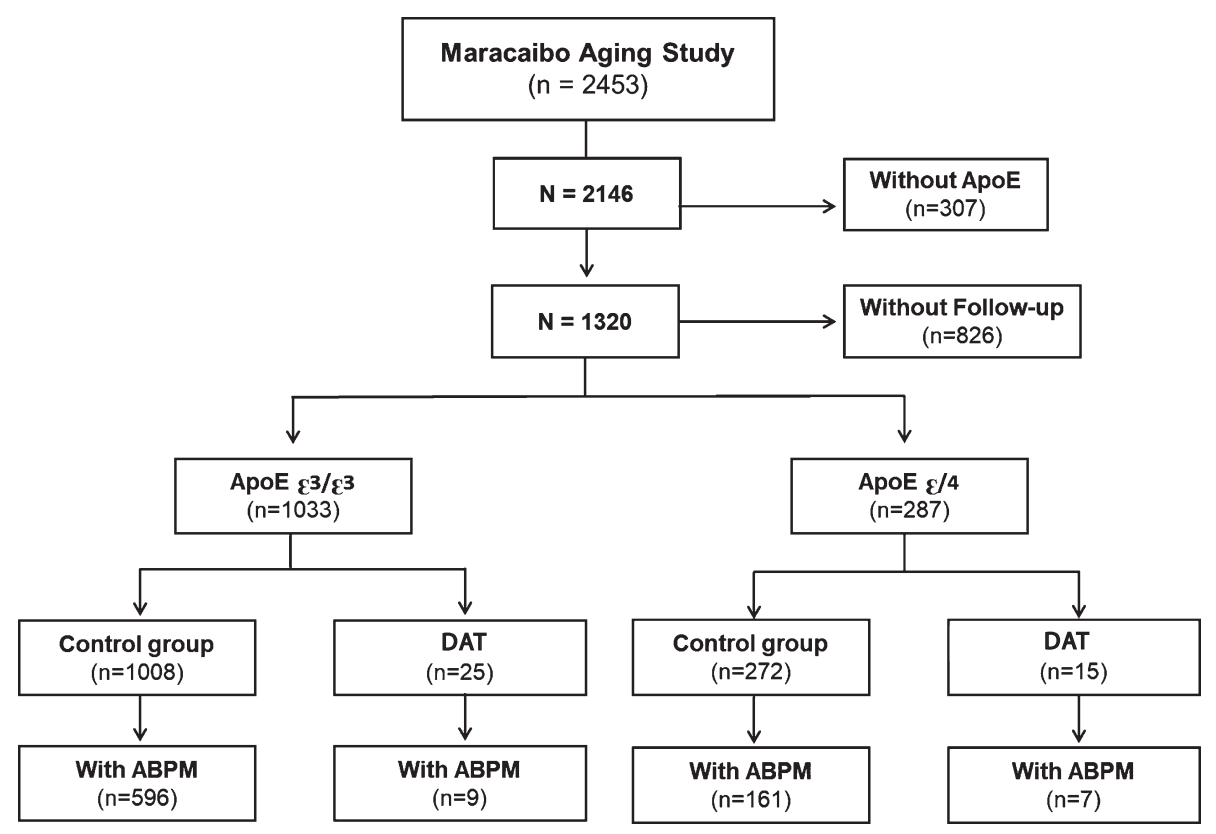

Fig. 1. Flow chart of the participant selection process.

data on $A P O E$ and DAT incidence. We then tested if the relationship between BP and DAT risk is influenced by $A P O E$ genotype, because previous studies suggested that continuous associations exist between DAT incidence and BP, even in the normal range of systolic and diastolic BP, and that this risk is modified by presence of comorbidities or other cardiovascular risk factors. Because ambulatory BP more accurately predicts target organ damage than office BP [11], we selected 773 subjects that also had 24-h ambulatory BP records. Informed consent was obtained for each participant or from a surrogate when appropriate, and the study was approved by the Institutional Review Board of the Cardiovascular Center at the University of Zulia in Maracaibo.

\section{Dementia assessment and differential diagnosis}

The standardized assessment and differential diagnosis of dementia in MAS has been previously described in detail $[1,12]$. Dementia cases included extensive, detailed follow-up and evaluations by a multidisciplinary team. First, a family interview was conducted by two trained social workers to followup with participants. An informant (usually a spouse or adult child residing in the same home as the participant) was identified as knowledgeable about the participant's daily activities and health issues. Information regarding changes in the abilities of the participant was collected using an adapted version of the Dementia Questionnaire [13], the Blessed Dementia Scale [14], and the Self-Maintaining and Instrumental Activities of Daily Living Scale [15], and a semi-structured interview for family history of dementia. Dementia diagnoses were made in consensus conference with physicians, psychologists, and social workers, using the diagnostic strategy developed for the Washington Heights-Inwood Columbia Aging Project in New York [16], including the Mini-Mental State Examination modified by Stern [17]. Dementia was identified if participants scored $\geq 1$ on the Clinical Dementia Rate (CDR) scale, and also exhibited cognitive impairment resulting in a functional decline in social or occupational activities not explained by other conditions. Types of dementia cases were classified following the Diagnostic and Statistical Manual of Mental Disorders, Fourth Edition (DSM-IV). Based on current recommendations, we termed AD as DAT [18].

\section{Blood pressure measurements}

At least two conventional BP measures were obtained for each participant by trained nurses at the examination center during baseline and each follow-up visit, using the appropriate cuff size and a validated automated device (Dynamap, XL), with the subjects in the sitting position. Ambulatory BP 
monitoring records were obtained using the 90207 SpaceLabs system, programmed to obtain readings every 15 minutes during the daytime (06:00 to 23:00) and every 30 minutes during nighttime (23:00 to 06:00). As reported elsewhere [19], the percentage of valid ambulatory BP monitoring measurements was $>80 \%$, with a median of 67 out of the 82 programmed recordings during a $24-\mathrm{h}$ period. To identify the decrease or increase in nocturnal BP levels in relation to daytime BP level, we used the night/day BP ratio multiplied by $100 \%$.

\section{Apolipoprotein E genotyping and other clinical measurements}

As previously reported for the MAS [20], APOE genotyping was performed using the polymerase chain reaction and $C f o \mathrm{I}$ digestion, under conditions described by Hixson and Vernier [21]. All six APOE gene variants were identified. Individuals with the $\varepsilon 3 / \varepsilon 4$ and $\varepsilon 4 / \varepsilon 4$ genotypes were grouped as $A P O E$ $\varepsilon 4$, and individuals with the $\varepsilon 3 / \varepsilon 3$ genotype were used as the reference group.

Participants underwent standardized physical and clinical evaluations. Laboratory assessments included hematology and blood biochemistry. Body mass index (BMI) was weight $(\mathrm{kg})$ divided by the square of height $\left(\mathrm{m}^{2}\right)$. Diabetes was defined as fasting glucose level $\geq 126 \mathrm{mg} / \mathrm{dL}$ or use of glucose-lowering medication. History of cardiovascular events included myocardial infarction, stroke, coronary bypass, angina pectoris, or congestive heart failure.

\section{Statistical analyses}

Descriptive information is presented as mean \pm standard deviation, and frequency as percentage. Significance of differences among $A P O E$ groups was determined using the chi-square test for categorical data, and t-test for continuous data. For each participant, person-years (p-y) to dementia was calculated as the number of years from baseline until 1) the time of onset, or 2) the time of the last assessment in which the individual was found not to have dementia, but subsequently remained in the study. Incidence per 1000 p-y was estimated as the number of new cases of dementia, divided by the at-risk p-y, multiplied by 1000 [22]. Confidence intervals were calculated assuming a Poisson distribution for the number of cases within each group. In exploratory analyses, we plotted the cumulative incidence of DAT by categories of nighttime systolic and diastolic BP level, while standardizing for sex and age (grouped as $<70,70$ to $<80$, and $\geq 80$ years).

Because hypertension is a shared risk factor for both death and DAT, the competing risk due to death might bias the association between BP and DAT [23, 24]. Individuals with elevated BP levels at baseline have an increased risk of death, and a proportion of them would die before the diagnosis of DAT. Therefore, we used the proportional sub-distribution hazards model developed by Fine and Gray [25] and modified by Chang et al. [26]. Multivariate Cox proportional models integrated subhazard ratios (Sub-HR) for DAT risk in the two APOE groups, based on conventional BP and ambulatory BP monitoring data. Covariables were selected according to significance differences in baseline characteristics between subjects who developed DAT and controls who did not. The association between night-to-day ratio and DAT was assessed by Cox proportional models without adjustment of sub-hazard ratios. Improvement in performance of competing Cox proportional regressions was assessed from change in the area under the curve (AUC), and by the log likelihood ratio and the generalized R2 statistic [27]. The AUC was assessed in the context of survival analysis using Harrell's C Statistic [28]. For database management and statistical analysis, we used the SAS software, version 9.4, maintenance level 5 (SAS Institute Inc., Cary, NC), and STATA (Version 14th). For all analyses, $p$ values less than 0.05 were considered statistically significant.

\section{RESULTS}

\section{Baseline characteristics and incidence of Alzheimer's disease}

MAS participants who were included in the present study showed some significant differences from those who were excluded (Supplementary Table 1). For example, the included subjects were younger on average, had a higher incidence of diabetes mellitus, and had a lower rate of cardiovascular disease than the excluded group.

APOE $\varepsilon 4$ carriers made up $22.2 \%$ of the study population, and baseline characteristics and BP measurements were similar for subjects with $A P O E-\varepsilon 4$ and $A P O E-\varepsilon 3 / \varepsilon 3$ (Supplementary Table 2). Individuals with $A P O E-\varepsilon 3 / \varepsilon 3$ who developed DAT were significantly older at baseline, had less education, 
lower BMI, and a lower rate of alcohol intake than those who did not develop DAT (Table 1). Individuals with $A P O E-\varepsilon 4$ who developed DAT were older at baseline, had less education, and had higher triacylglyceride levels than those who did not develop DAT. Based on these differences, age, sex, education, alcohol intake, triacylglycerides, and BMI were selected as covariables.

\section{Apolipoprotein E and incidence of dementia of the Alzheimer's type}

Follow-up time was not significantly different for the groups with $A P O E-\varepsilon 4 / \varepsilon 4$ and $A P O E-\varepsilon 3 / \varepsilon 3$ alleles (Supplementary Table 2). We followed individuals for an average of $5.3 \mathrm{y}$, with a total of $6,920 \mathrm{p}-\mathrm{y}$ (Supplementary Table 4). DAT incidence was highest in individuals with $A P O E-\varepsilon 4 / \varepsilon 4$ and lowest in participants with $A P O E-\varepsilon 3 / \varepsilon 3$. In comparison to those with $A P O E-\varepsilon 3 / \varepsilon 3$, individuals with the $A P O E-\varepsilon 3 / \varepsilon 4$ and $A P O E-\varepsilon 4 / \varepsilon 4$ alleles had significantly higher subhazard ratios for DAT. When $A P O E-\varepsilon 3 / \varepsilon 4$ and $\varepsilon 4 / \varepsilon 4$ were grouped and plotted in a survival graphic, those individuals had a significantly higher sub-hazard risk for DAT than those with $A P O E-\varepsilon 3 / \varepsilon 3$ (Supplementary Figure 1).

The risk for DAT was similar for women and men (Table 2). The presence of APOE- 84 was a significant risk factor for DAT among women, but not among men.

Table 1

Characteristics of individuals with versus without incident dementia of the Alzheimer's type (DAT), stratified by the presence of Apolipoprotein $\varepsilon 4$

\begin{tabular}{|c|c|c|c|c|}
\hline \multirow[t]{2}{*}{ Characteristics } & \multicolumn{2}{|c|}{$\begin{array}{c}A P O E-\varepsilon 3 / \varepsilon 3 \\
(n=1,033)\end{array}$} & \multicolumn{2}{|c|}{$\begin{array}{c}A P O E-\varepsilon 4 \\
(n=287)\end{array}$} \\
\hline & Dementia-free & DAT & Dementia-free & DAT \\
\hline & $(n=1008)$ & $(n=25)$ & $(n=272)$ & $(n=15)$ \\
\hline Age, $y$ & $65.9 \pm 8.0$ & $77.3 \pm 8.1^{\S}$ & $64.7 \pm 7.1$ & $71.7 \pm 4.7 \S$ \\
\hline Women, $n(\%)$ & $688(68.3)$ & $18(72.0)$ & $206(75.7)$ & $12(80.0)$ \\
\hline Level of education, $y$ & $6.1 \pm 4.1$ & $3.6 \pm 3.8^{\ddagger}$ & $6.3 \pm 4.3$ & $3.3 \pm 3.6^{\ddagger}$ \\
\hline History of smoking, $n(\%)$ & 468 (46.9) & $14(56.0)$ & $133(49.1)$ & $9(60.0)$ \\
\hline Alcohol intake, $n(\%)$ & $342(34.3)$ & $4(16.0)^{\dagger}$ & $86(31.7)$ & $3(20.0)$ \\
\hline Body mass index, $\mathrm{kg} / \mathrm{mt}^{2}$ & $21.7 \pm 4.2$ & $19.9 \pm 4.2^{\dagger}$ & $21.6 \pm 4.4$ & $21.8 \pm 6.9$ \\
\hline Diabetes mellitus, $n(\%)$ & $170(16.9)$ & $3(12.0)$ & $48(17.7)$ & $5(33.3)$ \\
\hline Conventional hypertension, $n(\%)$ & $825(81.8)$ & $21(84.0)$ & 209 (76.8) & $15(100.0)$ \\
\hline Antihypertensive treatment, $n(\%)$ & $313(31.1)$ & $4(16.0)$ & $81(29.9)$ & $5(33.3)$ \\
\hline History of CVD, $n(\%)$ & 137 (13.6) & $2(8.0)$ & $24(8.8)$ & $2(13.3)$ \\
\hline Serum creatine, $\mathrm{mg} / \mathrm{dL}$ & $0.9 \pm 0.3$ & $0.9 \pm 0.2$ & $0.9 \pm 0.6$ & $0.8 \pm 0.2$ \\
\hline Total cholesterol, mg/dL & $197.7 \pm 56.6$ & $193.6 \pm 54.2$ & $208.3 \pm 57.6$ & $210.4 \pm 45.3$ \\
\hline Triacylglycerides, mg/dL & $157.6 \pm 114$ & $138.2 \pm 116.2$ & $152.1 \pm 97.3$ & $204.1 \pm 116^{\dagger}$ \\
\hline Homocysteine, mg/dL & $13.6 \pm 5.8$ & $15.5 \pm 6.3$ & $13.5 \pm 4.7$ & $14.4 \pm 3.5$ \\
\hline Baseline MMSE score, & $44.0 \pm 7.4$ & $33.4 \pm 9.9 \S$ & $43.7 \pm 8.0$ & $35.9 \pm 8.9^{\S}$ \\
\hline Last MMSE score, & $43.2 \pm 8.3$ & $24.2 \pm 9.7^{\S}$ & $42.7 \pm 8.4$ & $24.8 \pm 12.4^{\S}$ \\
\hline Duration of follow-up, $y$ & $5.2 \pm 2.9$ & $5.6 \pm 3.2$ & $5.2 \pm 2.8$ & $7.5 \pm 3.1^{\ddagger}$ \\
\hline
\end{tabular}

CVD, cardiovascular diseases; MMSE, Mini-Mental State Examination modified by Stern. ${ }^{*} p<0.10 ;{ }^{\dagger} p<0.05 ;{ }^{\ddagger} p<0.01 ;{ }^{\S} p<0.001$.

Table 2

Risk of dementia of the Alzheimer's type by gender, and association with $A P O E-\varepsilon 4$ according to gender

\begin{tabular}{lcccc}
\hline & \multicolumn{3}{c}{ Dementia of Alzheimer's Type } \\
\cline { 2 - 4 } & $\begin{array}{c}\text { No. of cases/ } \\
\text { subjects at risk }\end{array}$ & Sub-HR* & $95 \%$ CI & $p$ \\
\hline Risk of DAT by gender & & & & \\
$\quad$ Women & $30 / 924$ & 1.80 & $0.63-5.11$ & 0.270 \\
$\quad$ Men & $10 / 396$ & 0.55 & $0.20-1.60$ & \\
Risk-association between & & & & \\
APOE- $\varepsilon 4$ and DAT by & & & & \\
gender & & 4.5 & $1.9-10.9$ & 0.001 \\
$\quad$ Women & $12 / 218$ & 4.3 & $0.9-20.3$ & 0.068 \\
$\quad$ Men & $3 / 69$ & & \\
\hline
\end{tabular}

HR, hazard ratio; CI, confident interval; DAT, dementia of the Alzheimer's type. *Sub-hazard ratio models were adjusted by age, education, alcohol intake, levels of triacylglycerides, and body mass index. ${ }^{\dagger}$ The risk-association between $A P O E-\varepsilon 4$ and DAT was estimated for women and men separately. 


\section{Blood pressure and incidence of dementia of the Alzheimer's type}

Subjects with the $A P O E-\varepsilon 4$ allele showed significant differences in BP between individuals with DAT and non-DAT controls, but subjects with APOE$\varepsilon 3$ did not (Supplementary Figure 2). Adjusted Cox models, that were proportional and considered death as a competitive risk, showed that nighttime systolic $\mathrm{BP}$ was a significant risk factor for the development of DAT in the APOE- $\varepsilon 4$ group (Fig. 2). However, conventional, 24-hour, diastolic, or daytime systolic BP did not predict development of DAT in the $A P O E-\varepsilon 4$ group, and none of the BP measurements predicted development in the $A P O E-\varepsilon 3$ group. When nighttime systolic and diastolic BP level were categorized, we observed that the cumulative incidence of DAT increased according to higher categories of nighttime systolic BP level $(p=0.023)$ (Fig. 3). The higher the systolic night-to-day ratio associated with DAT risk among APOE- $\varepsilon 4$ carriers. However, when the models were adjusted by 24-h BP level, the association did not remain significant (Table 3 ). Controlled nighttime systolic BP $<115 \mathrm{mmHg}$ was associated with lower risk for DAT (Supplementary Table 5).

\section{Improved model predicting dementia of the Alzheimer's type}

Based on results shown in Fig. 3, nighttime systolic $\mathrm{BP}$ was selected to assess improvement in the model performance (Table 4). All Harrell's Condordance
Statistic values were $\geq 0.829$, indicating a strong model. Although adding nighttime systolic BP to the base model for the total sample did not improve model fit, adding $A P O E-\varepsilon 4$ did significantly improve model fit. Adding nighttime systolic BP levels to the model with only the $A P O E-\varepsilon 4$ group also significantly improved model fit.

\section{DISCUSSION}

Our results indicated that high nocturnal systolic $\mathrm{BP}$ is a significant risk factor for DAT, but only among individuals carrying the $A P O E-\varepsilon 4$ allele. It is critically important to use ambulatory BP monitoring, rather than $\mathrm{BP}$ measurements, and $A P O E$ genotyping as predictors of dementia risk. This conclusion was based on a large sample of elderly Hispanics, whose data were adjusted for confounding factors (age, sex, education, alcohol intake, triacylglycerides, and body mass index), and death was considered as a competing risk.

Results of previous studies of hypertension and AD are inconsistent. Some showed no significant association in the elderly [24]; others concluded that the relationship was mediated by age $[4,29,30,31]$, with midlife hypertension being the strongest risk factor $[32,33]$. Our results provide robust evidence of the effect of hypertension on development of DAT in elderly Hispanics. Moreover, individuals in our cohort whose BP was controlled by antihypertensive treatment had reduced risk of DAT.

Our results show a significant interactive effect of $A P O E$ genotype and hypertension on risk for DAT.
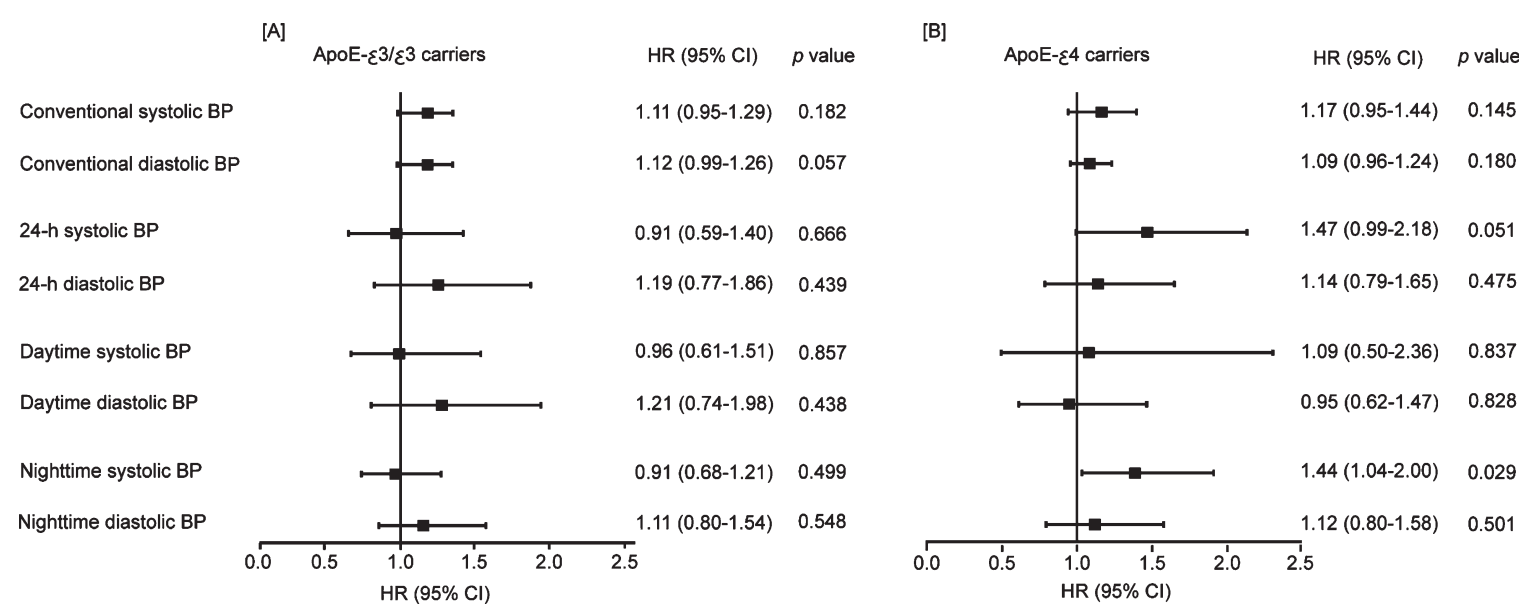

Fig. 2. Sub-Hazard Ratios for Dementia of Alzheimer's Type in Relation to Blood Pressure Measurements According to the Presence of $A P O E-\varepsilon 4$. Panel A contains the estimations among participants carrying the $A P O E-\varepsilon 3 / \varepsilon 3$. Meanwhile, panel B shows subjects carrying the $A P O E-\varepsilon 4$. The squares represent the sub-hazard ratios, and the lines aside show the $95 \%$ confident interval. The estimations were adjusted by age, sex, education, alcohol intake, triacylglycerides, and body mass index. 


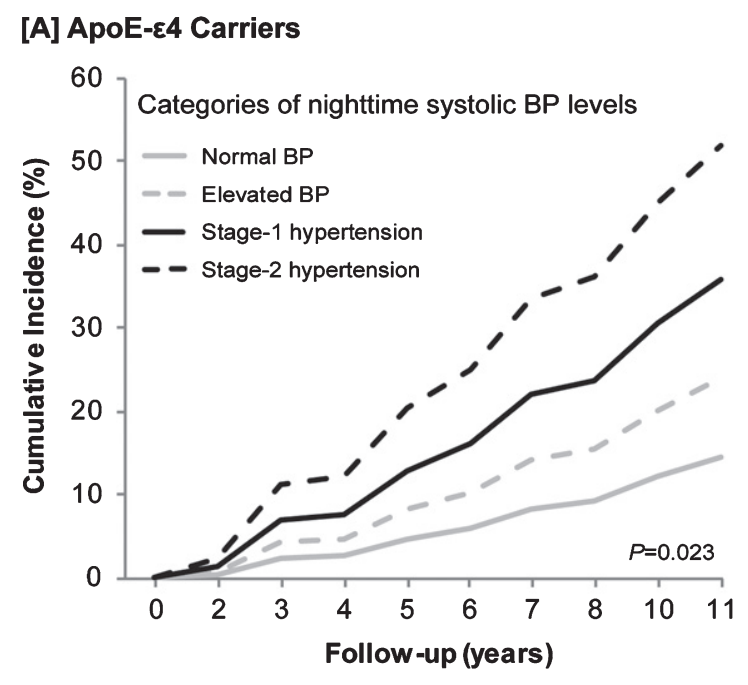

[B] ApoE- $\varepsilon 3 / \varepsilon 3$ Carriers

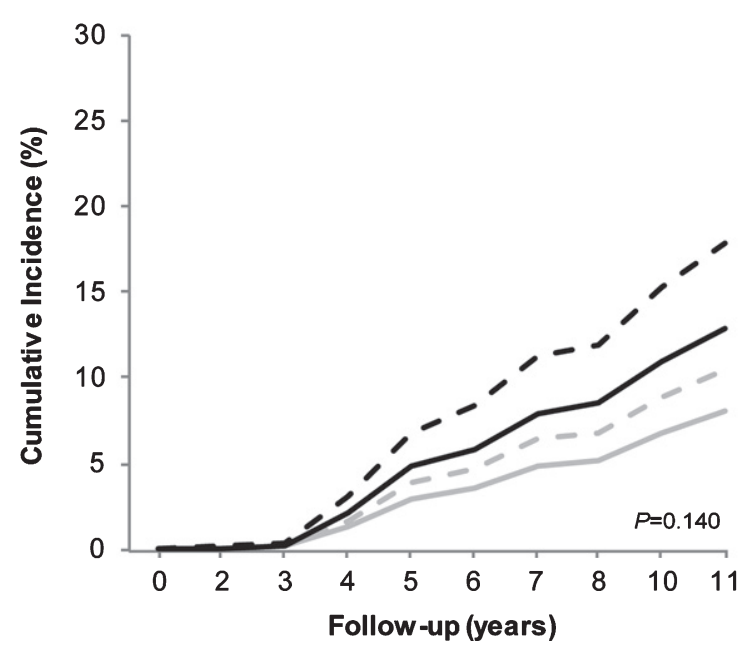

\section{[C] ApoE- $\varepsilon 4$ Carriers}

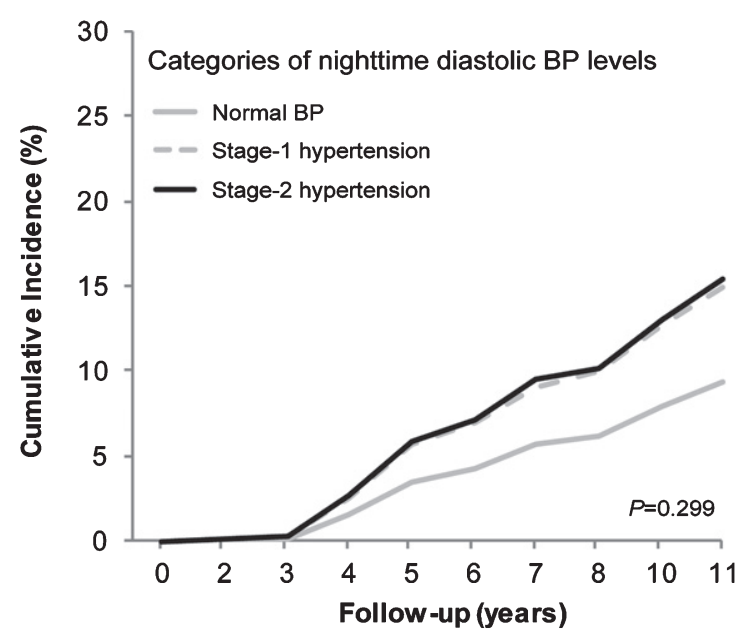

[D] ApoE- $\varepsilon 3 / \varepsilon 3$ Carriers

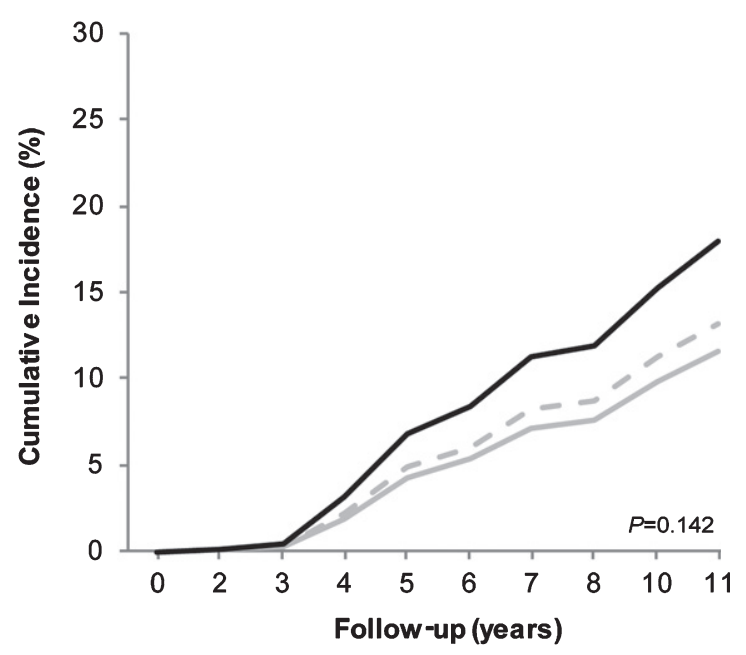

Fig. 3. Cumulative Incidence for Dementia of the Alzheimer's Type (DAT) According to Categories of Nighttime Systolic and Diastolic Blood Pressure Level. The incidence was standardized by sex and age (grouped as $<70, \geq 70$ to $<80$, and $\geq 80$ years). Panels A and B shows the incidence of DAT by categories of nighttime systolic blood pressure (BP) levels among participants carriers (A) and non-carriers (B)

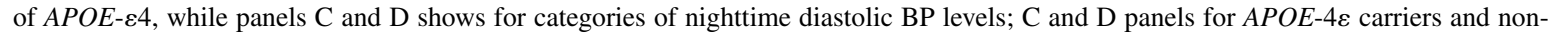
carriers; respectively. Categories of nighttime BP level were defined based on the 2017 American guideline [48]. Thresholds for nighttime systolic normal BP, elevated BP, stage- 1 , stage- 2 combined with severe hypertension were $<100, \geq 100$ to $<110, \geq 110$ to $<120, \geq 120 \mathrm{mmHg}$; respectively, meanwhile for nighttime diastolic normal BP, stage-1, stage-2 combined with severe hypertension were $<65$, $\geq 65$ to $<70$, $\geq 70 \mathrm{mmHg}$.

This supports previous conclusions that hypertensive individuals carrying at least one $A P O E-\varepsilon 4$ allele are at greater risk for cognitive decline, cerebrovascular disease, and high amyloid- $\beta$ accumulation than individuals with either factor alone [34, 35]. Geneenvironment [36, 37] and gene-gene [38] interactions have been shown to modulate the influence of $A P O E$ $\varepsilon 4$ as a risk factor for $\mathrm{AD}$, which might partly explain why the risk of $\mathrm{AD}$ among Hispanic $A P O E$ $\varepsilon 4$ carriers is higher than in non-carriers, but lower than in their White counterparts. The mechanisms by which the $A P O E-\varepsilon 4$ allele affects the association between $\mathrm{BP}$ and $\mathrm{AD}$ are not known. It has been hypothesized that vascular and genetic factors have a synergistic effect on brain impairment via increased susceptibility to accumulation of neural insults, cognitive decline, and amyloid- $\beta$ accumulation [34]. Some researchers have suggested that $A P O E-\varepsilon 4$ predisposes carriers to cerebrovasculature damage by hypertension [39]. 
Table 3

Association between night-to-day blood pressure ratio and dementia of the Alzheimer's type

\begin{tabular}{|c|c|c|c|c|c|c|}
\hline \multirow{2}{*}{$\begin{array}{l}\text { Association of }+10 \% \text { increase } \\
\text { of the night-to-day ratio and } \\
\text { DAT }\end{array}$} & \multicolumn{2}{|c|}{ Unadjusted } & \multicolumn{2}{|c|}{ Adjusted $^{\dagger}$} & \multicolumn{2}{|c|}{ Fully-adjusted $\ddagger$} \\
\hline & $\begin{array}{l}\text { Hazard ratio } \\
(95 \% \mathrm{CI})^{*}\end{array}$ & $p$ & $\begin{array}{l}\text { Hazard ratio } \\
(95 \% \mathrm{CI})^{*}\end{array}$ & $P$ & $\begin{array}{l}\text { Hazard ratio } \\
(95 \% \mathrm{CI})^{*}\end{array}$ & $p$ \\
\hline \multicolumn{7}{|l|}{ In the whole sample } \\
\hline $\begin{array}{l}\text { Night-to-day systolic BP } \\
\text { ratio }\end{array}$ & $1.88(1.17-3.03)$ & 0.009 & $1.30(0.74-2.27)$ & 0.360 & $1.19(0.64-2.21)$ & 0.580 \\
\hline $\begin{array}{l}\text { Night-to-day diastolic BP } \\
\text { ratio }\end{array}$ & $1.46(0.92-2.32)$ & 0.112 & $1.25(0.77-2.03)$ & 0.363 & $1.24(0.75-2.05)$ & 0.397 \\
\hline \multicolumn{7}{|l|}{ In $A P O E-\varepsilon 3 / \varepsilon 3$ carriers } \\
\hline ratio & & & & & & \\
\hline $\begin{array}{l}\text { Night-to-day diastolic BP } \\
\text { ratio }\end{array}$ & $1.19(0.61-2.32)$ & 0.617 & $1.08(0.48-2.41)$ & 0.853 & $1.02(0.41-2.52)$ & 0.971 \\
\hline \multicolumn{7}{|l|}{ In $A P O E-\varepsilon 4$ carriers } \\
\hline $\begin{array}{l}\text { Night-to-day systolic BP } \\
\text { ratio }\end{array}$ & $3.33(1.27-8.76)$ & 0.015 & $2.93(1.01-8.49)$ & 0.028 & $2.74(0.94-7.98)$ & 0.064 \\
\hline $\begin{array}{l}\text { Night-to-day diastolic BP } \\
\text { ratio }\end{array}$ & $2.41(0.93-6.26)$ & 0.070 & $1.75(0.51-5.92)$ & 0.372 & $1.80(0.52-6.25)$ & 0.356 \\
\hline
\end{tabular}

Table 4

Fit of Cox proportional regression models relating the dementia of the Alzheimer's type to nighttime systolic blood pressure levels and $A P O E-\varepsilon 4$

\begin{tabular}{|c|c|c|c|c|}
\hline \multirow[b]{2}{*}{ Models } & \multirow[b]{2}{*}{ C-Statistic* } & \multicolumn{3}{|c|}{ Likelihood test } \\
\hline & & $\chi^{2}$ Statistic & $p$ & $R 2(\%)^{\dagger}$ \\
\hline \multicolumn{5}{|l|}{ In the whole sample } \\
\hline+ Base model $1^{\ddagger}$ & 0.829 & 15.75 & $<0.001$ & NA \\
\hline $\begin{array}{l}\text { +Base model }{ }^{\ddagger}+\text { nighttime } \\
\text { systolic BP levels }\end{array}$ & 0.869 & 16.35 & 0.438 & $0.60 \%$ \\
\hline $\begin{array}{c}+ \text { Base model }^{\ddagger}+\text { nighttime } \\
\text { systolic BP levels }+A P O E-\varepsilon 4\end{array}$ & 0.909 & 24.27 & 0.004 & $7.92 \%$ \\
\hline \multicolumn{5}{|l|}{ In $A P O E-\varepsilon 3 / \varepsilon 3$ carriers } \\
\hline+ Base model ${ }^{\ddagger}$ & 0.948 & 20.54 & $<0.001$ & NA \\
\hline $\begin{array}{l}\text { +Base model }{ }^{\ddagger}+\text { nighttime } \\
\text { systolic BP levels }\end{array}$ & 0.949 & 20.62 & 0.780 & $0.08 \%$ \\
\hline \multicolumn{5}{|l|}{ In $A P O E-\varepsilon 4$ carriers } \\
\hline+ Base model ${ }^{\ddagger}$ & 0.889 & 12.34 & $<0.001$ & NA \\
\hline $\begin{array}{l}\text { +Base model }{ }^{\ddagger}+\text { nighttime } \\
\text { systolic BP levels }\end{array}$ & 0.925 & 16.27 & 0.046 & $3.93 \%$ \\
\hline
\end{tabular}

BP, blood pressure. *The c-statistic was estimated by using Harrell's Concordance Statistic. Values over 0.8 indicate a strong model; a value of 1 means that the model perfectly predicts those participants who will development dementia of Alzheimer's type and those who will not. ${ }^{\dagger}$ Basic model accounted for age, sex, education, alcohol intake, triacylglycerides, and body mass index. ${ }^{\ddagger} R^{2}$ is an estimate of the additional variance explained (https://apha.confex.com/apha/134am/ techprogram/paper_135906.htm).

Both $A P O E-\varepsilon 4$ and altered nocturnal dipping profile have been associated with increased white matter hyperintensity volume [40, 41]. Therefore, the results presented here support the notion that co-occurrence of $A P O E-\varepsilon 4$ and increased nighttime BP may increase the likelihood of small vessel disease, which in turn increases the likelihood of DAT development. The superior prognostic value of noc- turnal BP could be due to minimization of activity and mental stress during sleep, reflecting better the hemodynamic condition of the individual. Inflammation has been reported in association to both high nocturnal BP [42] and APOE- 44 [43], with potential deleterious effect in the blood-brain barrier, suggesting that $A P O E-\varepsilon 4$ could amplify the effect of high nocturnal $\mathrm{BP}$ on the brain. 
Our group previously found sex-related differences in the relationship between $A P O E-\varepsilon 4$ and $\mathrm{AD}$ prevalence [20]. In the present study, after accounting for death as competing risk, the association between $A P O E-\varepsilon 4$ and DAT incidence remained significant only among women. This result could be explained by physiopathological mechanisms related to sex, and/or social or environmental factors that influence mortality of men $<55 \mathrm{y}$ (the enrollment age of this study).

Nocturnal BP level is the best predictor of DAT incidence in elderly individuals carrying $A P O E-\varepsilon 4$, as shown by the improvement in our model performance when nighttime systolic BP levels were added to the base model. Nocturnal BP is also the best predictor of cardiovascular events in MAS participants as well as in other populations [11], and is an important factor determining the extent of cerebral white matter lesions [44], which is linked to amyloid deposition in AD patients [45], as well as to incidence of $\mathrm{AD}$ [46]. Thus, high nocturnal BP appears to have the greatest relevance to the physiopathological changes associated with development of DAT.

The present study has several limitations. First, our dementia diagnoses relied on extensive clinical evaluation, but were not confirmed by autopsy. Second, the number of individuals with both $A P O E$ genotyping and ambulatory BP monitoring records was relatively small $(n=773)$, reducing the power of our statistical analyses. These limitations are offset by several strengths: the longitudinal nature of the study, the relative homogeneous composition of the Hispanics studied, and the use of ambulatory BP monitoring, which provided a more accurate BP assessment than conventional BP measurements.

In summary, our data and model showed that, even after accounting for the competing risk of death, the association of hypertension and DAT remained significant, but only among carriers of $A P O E-\varepsilon 4$. Because the burden of cardiovascular risk factors, and therefore risk of death, is higher in $A P O E-\varepsilon 4$ than in $A P O E-\varepsilon 3 / \varepsilon 3$ carriers [47], stratification of risk based on both hypertension, particularly nocturnal BP, and presence of $A P O E-\varepsilon 4$ greatly improves prediction of risk for DAT. As hypertension is a common and modifiable risk factor among elderly patients, and DAT risk is reduced by treatment and control, physicians should be aware of the interactive influence of hypertension and the $A P O E-\varepsilon 4$ allele on risk of AD. Patients known to be hypertensive and $A P O E-\varepsilon 4$ carriers should undergo ambulatory BP monitoring. Finally, better understanding the role of $A P O E-\varepsilon 4$ in the vascular pathogenesis of $\mathrm{AD}$ is a promising approach to reducing risk of DAT.

\section{ACKNOWLEDGMENTS}

The authors thank Drs. Mary Carmen Nava, Ledys Mata, and Ney Alliey, who performed the follow-up assessments with G.E.M. and C.C. Sabrina Gonzalez, Elvilena Passeri, Carina Pacheco, and Eduardo Arteaga performed the neuropsychological assessments and participated in clinical discussions with G.P. and M.U. Lenys Araujo performed the preclinical assessments. Javier Aracena managed the database. Dr. Aldrin Molero contributed critically to the standardization of instruments used in the assessments. Mr. Fidencio Montero, a Maracaibo Aging Study (MAS) participant, provided rides to fellow participants and the MAS team for more than 10 years and helped to keep the refusal rate low. We particularly thank the volunteers of FundaConCiencia who worked hard to keep MAS participants engaged and enthusiastic. Most of all, we are grateful to the families of Santa Lucia who welcomed and trusted us and supported the participation of their elderly relatives. We also thank Mr. Edvin Jaimes for professionally processing all the illustrated figures. Dr. Jesus Melgarejo thanks the International Brian Research Organization (IBRO) for supporting his research training at the National University of Colombia Genetics Institute during July-December, 2018.

This research was supported by the GeneEnvironment Interaction in Cognition in Venezuela Families project, funded by the NIA-NIH under award numbers R01AG036469, 1 R03 AG05418601 (Maestre \& Terwilliger) and 1 P30 AG059305-01 (Maestre, de Erausquin and Gil).

Authors' disclosures available online (https:// www.j-alz.com/manuscript-disclosures/20-0430r1).

\section{SUPPLEMENTARY MATERIAL}

The supplementary material is available in the electronic version of this article: https://dx.doi.org/ 10.3233/JAD-200430.

\section{REFERENCES}

[1] Maestre GE, Mena LJ, Melgarejo JD, Aguirre-Acevedo DC, Pino-Ramirez G, Urribarri M, Chacon IJ, Chavez CA, Falque-Madrid L, Gaona CA, Terwilliger JD, Lee JH Scarmeas N (2018) Incidence of dementia in elderly 
Latin Americans: Results of the Maracaibo Aging Study. Alzheimers Dement 14, 140-147.

[2] Mehta KM, Yeo GW (2017) Systematic review of dementia prevalence and incidence in United States race/ethnic populations. Alzheimers Dement 13, 72-83.

[3] Kjeldsen SE, Narkiewicz K, Burnier M, Oparil S (2018) Intensive blood pressure lowering prevents mild cognitive impairment and possible dementia and slows development of white matter lesions in brain: The SPRINT Memory and Cognition IN Decreased Hypertension (SPRINT MIND) study. Blood Press 27, 247-248.

[4] Petitti DB, Crooks VC, Buckwalter JG, Chiu V (2005) Blood pressure levels before dementia. Arch Neurol 62, 112-116.

[5] Thomas IC, Allison MA (2019) Hypertension in Hispanics/Latinos: Epidemiology and considerations for management. Curr Hypertens Rep 21, 43.

[6] Hernandez-Hernandez R, Silvia H, Velasco M, Pellegrini F, Macchia A, Escobedo J, Vinueza R, Schargrodsky H, Champagne B, Pramparo P, Wilson E; CARMELA Study Investigators (2010) Hypertension in seven Latin American cities: The Cardiovascular Risk Factor Multiple Evaluation in Latin America (CARMELA) study. J Hypertens 28, 24-34.

[7] Chow CK, Teo KK, Rangarajan S, Islam S, Gupta R, Avezum A, Bahonar A, Chifamba J, Dagenais G, Diaz R (2013) Prevalence, awareness, treatment, and control of hypertension in rural and urban communities in high-, middle-, and low-income countries. JAMA 310, 959-968.

[8] Rubinstein AL, Irazola VE, Calandrelli M, Chen CS, Gutierrez L, Lanas F, Manfredi JA, Mores N, Poggio R, Ponzo J (2016) Prevalence, awareness, treatment, and control of hypertension in the Southern Cone of Latin America. Am J Hypertens 29, 1343-1352.

[9] Fitten L, Ortiz F, Ponton M (2001) Frequency of Alzheimer's disease and other dementias in a community outreach sample of Hispanics. J Am Geriatr Soc 49, 13011308.

[10] Farrer LA, Cupples LA, Haines JL, Hyman B, Kukull WA, Mayeux R, Myers RH, Pericak-Vance MA, Risch N, Van Duijn CM (1997) Effects of age, sex, and ethnicity on the association between apolipoprotein E genotype and Alzheimer's disease: A meta-analysis. JAMA 278, 13491356.

[11] Yang WY, Melgarejo JD, Thijs L, Zhang ZY, Boggia J, Wei FF, Hansen TW, Asayama K, Ohkubo T, Jeppesen J, Dola E, Stolarz-Skrzypek K, Malyutina S, Casiglia E, Lind L, Filipovsky J, Maestre GE, Li Y, Wang JG, Imai Y, O'Brien E, Verhamme P, Staessen JA (2019) Association of office and ambulatory blood pressure with mortality and cardiovascular outcomes. JAMA 322, 409-420.

[12] Maestre GE, Pino-Ramirez G, Molero AE, Silva ER, Zambrano R, Falque L, Gamero MP, Sulbaran TA (2002) The Maracaibo Aging Study: Population and methodological issues. Neuroepidemiology 21, 194-201.

[13] Kawas C, Segal J, Stewart WF, Corrada M, Thal LJ (1994) A validation study of the Dementia Questionnaire. Arch Neurol 51, 901-906.

[14] Blessed G, Tomlinson BE, Roth M (1968) The association between quantitative measures of dementia and of senile change in the cerebral grey matter of elderly subjects. $\mathrm{Br} J$ Psychiatry 114, 797-811.

[15] Lawton MP, Brody EM (1969) Assessment of older people: Self-maintaining and instrumental activities of daily living. Gerontologist 9, 179-186.
[16] Stern Y, Andrews HF, Pittman J, Sano M, Tatemichi T, Lantigua RA Mayeux R (1992) Diagnosis of dementia in a heterogeneous population: Development of a neuropsychological paradigm-based diagnosis of dementia and quantified correction for the effects of education. Arch Neurol 49, 453-460.

[17] Stern Y, Sano M, Paulson J, Mayeux R (1987) Modified mini-mental state examination: Validity and reliability. $\mathrm{Neu}$ rology $37,179$.

[18] Jack Jr CR, Bennett DA, Blennow K, Carrillo MC, Dunn B, Haeberlein SB, Holtzman DM, Jagust W, Jessen F, Karlawish J, Liu E, Molinuevo JL, Montine T, Phelps C, Rankin KP, Rowe CC, Scheltens P, Siemers E, Snyder HM, Sperling R; Contributors (2018) NIA-AA research framework: Toward a biological definition of Alzheimer's disease. Alzheimers Dement 14, 535-562.

[19] Melgarejo JD, Maestre GE, Thijs L, Asayama K, Boggia J, Casiglia E, Hansen TW, Imai Y, Jacobs L, Jeppesen J, Kawecka-Jaszcz K, Kuznetsova T, Li Y, Malyutina S, Nikitin Y, Ohkubo T, Stolarz-Skrzypek K, Wang JG, Staessen JA; International Database on Ambulatory Blood Pressure in Relation to Cardiovascular Outcomes (IDACO) Investigators (2017) Prevalence, treatment, and control rates of conventional and ambulatory hypertension across 10 populations in 3 continents. Hypertension 70, 50-58.

[20] Molero AE, Pino-Ramirez G, Maestre GE (2001) Modulation by age and gender of risk for Alzheimer's disease and vascular dementia associated with the apolipoprotein Ee4 allele in Latin Americans: Findings from the Maracaibo Aging Study. Neurosci Lett 307, 5-8.

[21] Hixson JE, Vernier DT (1990) Restriction isotyping of human apolipoprotein $\mathrm{E}$ by gene amplification and cleavage with HhaI. J Lipid Res 31, 545-548.

[22] Breslow NE, Day NE, Heseltine E (1980) Statistical methods in cancer research. Volume I - The analysis of case-control studies. IARC Sci Publ, pp. 5-338.

[23] Ott A, Breteler MB, Harskamp FV, Stijnen T, Hofman A (1998) Incidence and risk of dementia: The Rotterdam Study. Am J Epidemiol 147, 574-580.

[24] Skoog I, Nilsson L, Persson G, Lernfelt B, Landahl S, Palmertz B, Andreasson LA, Oden A, Svanborg A (1996) 15-year longitudinal study of blood pressure and dementia. Lancet 347, 1141-1145.

[25] Fine JP, Gray RJ (1999) A proportional hazards model for the subdistribution of a competing risk. J Am Stat Assoc 94 , 496-509.

[26] Chang CC, Zhao Y, Lee CW, Ganguli M (2012) Smoking, death, and Alzheimer's disease: A case of competing risks. Alzheimer Dis Assoc Disord 26, 300-306.

[27] Gillespie BW (2006) Use of generalized Rsquared in Cox regression (http://apha.confex.com/ apha/134am/techprogram/paper_135906.htm). American Public Health Association Scientific Session and Event Listing

[28] Exalto LG, Quesenberry CP, Barnes D, Kivipelto M, Biessels GJ, Whitmer RA (2014) Midlife risk score for the prediction of dementia four decades later. Alzheimers Dement 10, 562-570.

[29] Posner HB, Tang MX, Luchsinger J, Lantigua R, Stern Y, Mayeux R (2002) The relationship of hypertension in the elderly to AD, vascular dementia, and cognitive function. Neurology 58, 1175-1181.

[30] Morris MC, Scherr PA, Hebert LE, Glynn RJ, Bennett DA, Evans DA (2001) Association of incident Alzheimer disease and blood pressure measured from 13 years before to 2 years 
after diagnosis in a large community study. Arch Neurol 58, 1640-1646.

[31] Qiu C, Winblad B, Fratiglioni L (2005) The age-dependent relation of blood pressure to cognitive function and dementia. Lancet Neurol 4, 487-499.

[32] Kivipelto M, Helkala EL, Laakso MP, Hanninen T, Hallikainen M, Alhainen K, Iivonen S, Mannermaa A, Tuomilehto J, Nissinen A (2002) Apolipoprotein E4 allele, elevated midlife total cholesterol level, and high midlife systolic blood pressure are independent risk factors for late-life Alzheimer disease. Ann Intern Med 137, 149-155.

[33] Ninomiya T, Ohara T, Hirakawa Y, Yoshida D, Doi Y, Hata J, Kanba S, Iwaki T, Kiyohara Y (2011) Midlife and latelife blood pressure and dementia in Japanese elderly: The Hisayama study. Hypertension 58, 22-28.

[34] Rodrigue KM, Rieck JR, Kennedy KM, Devous MD, DiazArrastia R, Park DC (2013) Risk factors for $\beta$-amyloid deposition in healthy aging: Vascular and genetic effects. JAMA Neurol 70, 600-606.

[35] De Frias CM, Schaie KW, Willis SL (2014) Hypertension moderates the effect of APOE on 21-year cognitive trajectories. Psychol Aging 29, 431-439.

[36] Lahiri DK, Sambamurti K, Bennett DA (2004) Apolipoprotein gene and its interaction with the environmentally driven risk factors: Molecular, genetic and epidemiological studies of Alzheimer's disease. Neurobiol Aging 25, 651-660.

[37] Mayeux R, Ottman R, Maestre G, Ngai C, Tang MX, Ginsberg H, Chun M, Tycko B, Shelanski M (1995) Synergistic effects of traumatic head injury and apolipoprotein-epsilon4 in patients with Alzheimer's disease. Neurology 45, 555557.

[38] Wijsman EM, Pankratz ND, Choi Y, Rothstein JH, Faber KM, Cheng R, Lee JH, Bird TD, Bennett DA, Diaz-Arrastia $\mathrm{R}$ (2011) Genome-wide association of familial late-onset Alzheimer's disease replicates BIN1 and CLU and nominates CUGBP2 in interaction with APOE. PLoS Genet 7, e1001308.

[39] Tai LM, Thomas R, Marottoli FM, Koster KP, Kanekiyo T, Morris AW, Bu G (2016) The role of APOE in cerebrovascular dysfunction. Acta Neuropathol 131, 709-723.

[40] Lyall DM, Cox SR, Lyall LM, Celis-Morales C, Cullen B, Mackay DF, Ward J, Strawbridge RJ, McIntosh AM, Sattar N (2019) Association between APOE e4 and white matter hyperintensity volume, but not total brain volume or white matter integrity. Brain Imaging Behav, doi: 10.1007/s11682-019-00069-9
[41] Chesebro AG, Melgarejo JD, Leendertz R, Igwe KC, Lao PJ, Laing KK, Rizvi B, Budge M, Meier IB, Calmon G (2020) White matter hyperintensities mediate the association of nocturnal blood pressure with cognition. Neurology 94, e1803-e1810.

[42] Kaya MG, Yarlioglues M, Gunebakmaz O, Gunturk E, Inanc T, Dogan A, Kalay N, Topsakal R (2010) Platelet activation and inflammatory response in patients with non-dipper hypertension. Atherosclerosis 209, 278-282.

[43] Montagne A, Nation DA, Sagare AP, Barisano G, Sweeney MD, Chakhoyan A, Pachicano M, Joe E, Nelson AR, D’Orazio LM, Buennael DP, Harrington MG, Benzinger TLS, Fagan AM, Ringman JM, Schneider LS, Morris JC, Reiman EM, Caselli RJ, Chui HC, Tcw J, Chen Y, Pa J, Conti PS, Law M, Toga AW, Zlokovic BV (2020) APOE4 leads to blood-brain barrier dysfunction predicting cognitive decline. Nature 581, 71-76.

[44] Sander D, Winbeck K, Klingelhofer J, Conrad B (2000) Extent of cerebral white matter lesions is related to changes of circadian blood pressure rhythmicity. Arch Neurol 57, 1302-1307.

[45] Grimmer T, Faust M, Auer F, Alexopoulos P, Förstl H, Henriksen G, Perneczky R, Sorg C, Yousefi BH, Drzezga A (2012) White matter hyperintensities predict amyloid increase in Alzheimer's disease. Neurobiol Aging 33, 27662773.

[46] Brickman AM, Provenzano FA, Muraskin J, Manly JJ, Blum S, Apa Z, Stern Y, Brown TR, Luchsinger JA, Mayeux R (2012) Regional white matter hyperintensity volume, not hippocampal atrophy, predicts incident Alzheimer disease in the community. Arch Neurol 69, 1621-1627.

[47] Hestad KA, Engedal K, Whist JE, Farup PG (2016) The effect of ApoE e4 on blood pressure in patients with and without depression. Neuropsychiatr Dis Treat 12, 13651370 .

[48] Whelton PK, Carey RM, Aronow WS, Casey DE Jr, Collins KJ, Dennison Himmelfarb C, DePalma SM, Gidding S, Jamerson KA, Jones DW, MacLaughlin EJ, Muntner P, Ovbiagele B, Smith SC Jr, Spencer CC, Stafford RS, Taler SJ, Thomas RJ, Williams KA Sr, Williamson JD, Wright JT Jr. (2018) 2017 ACC/AHA/AAPA/ABC/ACPM/AGS/ $\mathrm{APhA} / \mathrm{ASH} / \mathrm{ASPC} / \mathrm{NMA} / \mathrm{PCNA}$ guideline for the prevention, detection, evaluation, and management of high blood pressure in adults: A report of the American College of Cardiology/American Heart Association Task Force on Clinical Practice Guidelines. J Am Coll Cardiol 71, e127-e248. 